\section{Screening for Resistance to Zucchini yellow mosaic virus in the Watermelon Germplasm}

\author{
Nihat Guner \\ Sakata Seed America, Inc. Morgan Hill, CA 95037
}

Zvezdana Pesic-VanEsbroeck

Department of Entomology and Plant Pathology, North Carolina State University, Raleigh, NC 27695

Luis A. Rivera-Burgos ${ }^{1}$ and Todd C. Wehner

Department of Horticultural Science, North Carolina State University, Raleigh, NC 27695

Additional index words. Citrullus, germplasm, plant introduction, strain

\begin{abstract}
The Florida strain of Zucchini yellow mosaic virus (ZYMV-FL) is one of the major viral diseases of watermelon [Citrullus lanatus (Thunb.) Matsum. \& Nakai]. Although some screening has been performed for ZYMV resistance in watermelon, the germplasm collection has not been screened extensively for resistance. The objectives of this study were to screen the U.S. Department of Agriculture (USDA) watermelon germplasm collection for ZYMV resistance and to verify the disease rating for the most resistant and most susceptible accessions. We used a randomized complete block with four replications, 1613 PI accessions, and 41 cultivars. 'Charleston Gray' and 'Crimson Sweet' susceptible controls were used to verify that the $\mathrm{ZYMV}$ inoculum was virulent. After the last rating, an enzyme-linked immunosorbent assay (ELISA) was performed to determine the presence of a virus in the plant tissue. The PI accessions with high resistance to ZYMV-FL that also exhibited resistance to other watermelon viruses were PI 595203, PI 386015, PI 386016, PI 386024, PI 386025, PI 386026, PI 244018, PI 244019, PI 485583, PI 494528, and PI 494529. The ZYMV-FL retest of the most resistant 46 PI accessions showed that there were some escapes. Sixteen resistant PI accessions had a rating of 3.0 or less for the average and maximum ratings: PI 595203, PI 537277, PI 560016, PI 386016, PI 386019, PI 485580, PI 494529, PI 595200, PI 494528, PI 595201, PI 386025, PI 494530, PI 386015, PI 386021, PI 386026, and PI 596662. Overall, PI 595203 had the highest resistance according to both the germplasm screening and the retest studies.
\end{abstract}

Watermelon [Citrullus lanatus (Thunb.) Matsum. \& Nakai] is a major cucurbit crop that accounts for $7.5 \%$ of the world area devoted to vegetable crops (FAO, 2015). There are 3.4 million ha of watermelon grown in the world, with China and Middle Eastern countries being the major producers and consumers (FAO, 2015). Watermelon is grown for its fleshy, juicy, sweet fruit. Mostly eaten fresh, watermelon is delicious and refreshing, especially during hot weather (PerkinsVeazie et al., 2001). In the United States, watermelon is used fresh as a dessert or in salads. U.S. production is concentrated in Florida, California, Texas, Georgia, and North Carolina (USDA, 2017). Production has increased from 1.2 million $\mathrm{Mg}$ in 1987 to 5.1 million $\mathrm{Mg}$ in 2017 , with a current farm value of $\$ 579$ million (USDA, 2017).

Worldwide, more than 10 viruses are known to be limiting factors for commercial watermelon production (Romay et al., 2014;

Received for publication 21 June 2018. Accepted for publication 19 Nov. 2018.

${ }^{1}$ Corresponding author. E-mail: lariver2@ncsu. edu. not grown. Along with the Cucurbitaceae, species in 11 families of dicotyledons are considered diagnostic hosts (Tiwari and Rao, 2014). The virus infects all the agriculturally important species of Cucurbitaceae (Provvidenti, 1991). ZYMV was first described in 1981 in squash grown in northern Italy and France, where it was named Muskmelon yellow stunt virus (Lisa and Dellavalle, 1981; Tiwari and Rao, 2014). Within one decade, ZYMV spread to the major cucurbit-producing regions worldwide. Symptoms of ZYMV include yellow mosaic, stunting, blistering, and laminar reduction on leaves, and the development of knobby areas on fruit can lead to a reduction in the marketable yield of squash, melon, watermelon, cucumber, and other cultivated cucurbits (Nagendran et al., 2017). The severity of infection depends on the age of the plants at infection, the strain of ZYMV, and the environment, particularly temperature (Desbiez and Lecoq, 1997).

ZYMV is a potyvirus with flexuous rods $\approx 750 \mathrm{~nm}$ long that contain a single strand of RNA (Coutts et al., 2011; Tiwari and Rao, 2014). Approximately 25 strains of ZYMV have been identified, and they differ in virulence, symptom severity, and the ability to induce symptoms in plants carrying genes for resistance (Desbiez and Lecoq, 1997). The major strains represented in the United States are the Connecticut strain (ZYMV-CT) and the Florida strain (ZYMVFL) (Brown, 2001). In the 1990s, Provvidenti identified a new ZYMV strain infecting cucurbit fields in Beijing, China (ZYMVCH) (Provvidenti, 1991). Plants infected with any of the ZYMV strains reduced their photosynthetic capacity and displayed stunted growth, deformed fruit, and early mortality (Guner and Wehner, 2008).

Major virus control methods include the use of insecticides, herbicides, reflective mulches, stylet oils, windbreaks, sequential plantings, avoiding seasons or locations with high aphid populations, and pathogenspecific genetic resistance (Brown, 2001). However, these cultural and chemical controls have limited effectiveness and can be expensive. Therefore, genetic resistance remains the simplest, most effective, and most efficient method of limiting losses to virus diseases (Levi et al., 2016; Nagendran et al., 2017; Webb and Tyson, 1997). Virusresistant watermelons have been identified in germplasm collections and by creating genetically modified organisms using genes for the coat protein from the virus (Coutts et al., 2011; Fuchs and Gonsalves 1995; Namba et al., 1992).

The watermelon germplasm collection has been screened for resistance to viral diseases on several occasions. Resistant PI accessions were identified for ZYMV (Boyhan et al., 1992; Provvidenti, 1991), WMV (Gillaspie and Wright 1993), and PRSV-W (Strange et al., 2002). In the case of ZYMV, researchers have identified PI accessions in several cucurbit species as resistant to ZYMV, and the inheritance of resistance has also been determined. Sources of resistance to ZYMV have also been identified for cucumber 
(Cucumis sativus), melon (Cucumis melo), and squash (Cucurbita spp.). ZYMV resistance is controlled by a single recessive gene in cucumber (Cardoso et al., 2010; Kabelka et al., 1997) and by a single dominant gene in melon (Park et al., 2004; Pitrat and Lecoq, 1984) and squash (Paris and Brown, 2005).

Watermelon germplasm was first screened for resistance to ZYMV by Provvidenti (1991), who used 68 PI accessions, breeding lines, and commercial cultivars. Provvidenti (1991) reported ZYMV resistance in four PI accessions from Zimbabwe (PI 482322, PI 482299, PI 482261, and PI 482308). Resistance was specific to the Florida strain (ZYMV-FL). Some accessions of the Nigerian Egusi watermelon (PI 494528 and PI 494532) were resistant to ZYMV that were not strainspecific (Provvidenti, 1986). However, that resistance was temperature-dependent and usually expressed in warm or hot climates. The watermelon germplasm was also screened for ZYMV resistance by Boyhan et al. (1992), who tested 153 PI accessions, breeding lines, and commercial cultivars. They found new sources of resistance to ZYMV in PI 386025, PI 386026 (both C. colocynthis), and PI 595203 (C. mucosospermus). They also confirmed the resistance of PI 482261 ( $C$. amarus) and PI 494528 (C. mucosospermus). At that time, it was reported that the resistance of PI 482261 was controlled by a single recessive gene, $z y m-F L$ (Provvidenti, 1991). Later, Xu et al. (2004) studied the inheritance of resistance to Zucchini yellow mosaic virus-China strain (ZYMV-CH) in PI 595203. They reported that resistance to ZYMV-CH was conferred by a single recessive gene, for which the symbol zym- $\mathrm{CH}$ was suggested. A single recessive gene (zym$F L$ ) was found to control the high level of resistance to the ZYMV-FL strain in PI 595203 (Guner et al., 2018b). The eIF4E gene was demonstrated to be associated with the ZYMV-FL resistance identified in PI595203, and molecular markers have been developed for use in cultivar development (Ling et al., 2009). An advanced watermelon breeding line with resistance to ZYMV has been developed using marker-assisted selection (Levi et al., 2016).

The USDA germplasm collection has more than 1600 watermelon PIs. Many PI accessions were added to the watermelon germplasm collection since the collection was first screened for ZYMV resistance in 1991. So far, only 221 PI accessions, breeding lines, and commercial cultivars have been screened for ZYMV resistance in the studies conducted by Provvidenti (1991) and Boyhan et al. (1992), representing $14 \%$ of the collection. Therefore, there is a possibility of identifying additional sources of resistance to ZYMV by evaluating more accessions. The objectives of this study were to screen the USDA watermelon germplasm collection along with available cultivars to identify additional sources of resistance to ZYMV and to verify resistance of PI accessions that were previously identified. Accessions with resistance to ZYMV could be used in breeding programs to develop improved watermelon cultivars.

\section{Materials and Methods}

Plant material. A total of 1654 Citrullus accessions (1613 PI and 41 cultivars) were obtained from the Southern Regional Plant Introduction Station in Griffin, GA. The PI accessions originated in 68 different countries, with 46 countries having fewer than 10 accessions each. Countries with the most accessions in the collection were Turkey (310), former Yugoslavia (185), Zimbabwe (156), India (151), Spain (77), China (73), Zambia (68), South Africa (58), Nigeria (49), Iran (41), United States (33), and Syria (31). The susceptible Charleston Gray and Crimson Sweet cultivars were used as controls and to maintain the ZYMV inoculum.

Planting and management. Two studies were performed, a germplasm screening and a retest. These studies were performed in North Carolina State University Plant Pathology and Horticultural Science greenhouses. The greenhouse temperatures ranged from 23 to $43{ }^{\circ} \mathrm{C}$ during the day and from 12 to $24{ }^{\circ} \mathrm{C}$ at night. The germplasm screening study was arranged in a randomized complete block design with four replications of the 1654 accessions. Each plot was a $100-\times 100-\mathrm{m}^{2}$ pot $(600 \mathrm{~mL}$ volume) filled with a soil-less mix (Canadian sphagnum peat moss, perlite, vermiculite, processed pine bark). Plants were fertilized weekly with $150 \mathrm{mg} \cdot \mathrm{kg}^{-1}$ Peters Professional 20-20-20 N-P-K (Scotts-Sierra Horticultural Products Company, Marysville, $\mathrm{OH}$ ). We planted two seeds per pot and thinned to one based on previous experience with Citrullus germplasm experiments (Gusmini et al., 2017). We preferred to use single-plant plots because this permitted the entire germplasm collection to be tested in each replication. In addition to the accessions tested, there were 10 control plants per replication of 'Charleston Gray' that were inoculated with the virus and 10 plants of 'Charleston Gray' that were not inoculated. The inoculated controls served as a verification of viral infection and the uninoculated controls served as an indicator of other plant stresses and diseases in the greenhouse that might confound symptom expression.

Inoculum preparation and inoculation. The virus isolate was obtained from E. Hiebert (University of Florida, Gainesville, FL). Three isolates of ZYMV-FL were tested to determine virulence (data not shown). The ZYMV-FL isolate used for the screening study was a subculture of isolate 2088, a severe ZYMV isolate described by Wisler et al. (1995). The virus isolate 2088 was maintained on 'Gray Zucchini' squash (Cucurbita pepo L.) from Seminis Vegetable Seeds (Woodland, CA) and susceptible watermelon cultivars. All 'Gray Zucchini' squash plants were seeded in metromix 200 (Scotts-Sierra Horticultural Products Company, Marysville, $\mathrm{OH}$ ) in clay pots with a $160-\mathrm{mm}$ diameter $(1550$ $\mathrm{mL}$ volume).

The inoculum was made by grinding infected 'Gray Zucchini' squash leaves using a mortar and pestle in $0.02 \mathrm{M}$ phosphate buffer (pH 7.0). The leaf-to-buffer ratio was 1:5 (1 g infected leaf to $5 \mathrm{~mL}$ buffer). We used the rub method to inoculate 'Gray Zucchini' squash (to increase the inoculum) and watermelon plants during the screening and retest studies (Guner et al., 2002). Plants were inoculated at least two times by dusting one leaf on each 3-week-old plant (first true leaf stage) with 800-mesh carborundum, and then applying the inoculum to the leaf with a pestle that was rotated in a circular motion 8 to 10 times, as if painting the leaf with inoculum. After inoculation, carborundum was rinsed off the leaves to improve light interception, and the plants were maintained in aphid-proof cages.

Data collection. Two weeks after the first inoculation, plants were rated weekly at least 6 times on a scale of 1 to 9 based on the severity of viral symptoms $(1=$ none; $2=$ tendrils absent; $3=$ tendrils absent, slightly stunted growth; $4=$ mosaic patches and/or necrotic spots on leaves; $5=$ leaves near apical meristem deformed, meristem yellow and reduced in size; $6=$ apical meristem withered and brown; $7=$ apical meristem dead with basal leaves dying; $8=$ most leaves dead, main stem green/yellow; $9=$ plant dead) (Guner et al., 2002). After the last rating, the 1654 accessions were tested in duplicate by ELISA (Agdia Incorporated, Elkhart, IN) to determine the presence of the virus in the leaf tissue using a mix of the top five leaves. We calculated the average absorbance values for each set of duplicate standards and duplicate samples. Duplicates were within $20 \%$ of the mean. Plants were classified as resistant or susceptible based on their rank relative to the estimated mean value of the disease severity scale (5.0) and ELISA test results. Plants that did not have the virus in their system (according to ELISA test results) and had an average rating less than 5.0 were considered resistant, and plants with the virus in their system and an average rating more than 5.0 were considered susceptible (Strange et al., 2002).

Retest. This study was performed after the completion of germplasm screening to verify the reaction of the most resistant and susceptible accessions and to rescreen the missing cultigens that were missing from at least two replications during the germplasm screening. This study used the same statistical design of the germplasm screening study with only 98 accessions and one susceptible control ('Crimson Sweet'). All other methods were the same as those used for the screening study.

Statistical analysis. Data were summarized as the average and maximum ratings for the 1,654 cultigens. The maximum rating was useful for distinguishing resistance among cultigens; early ratings have many cultigens with only slight disease symptoms. Data were analyzed using the means, analysis of variance (ANOVA), correlation, and general linear model procedures of the SAS statistical package (SAS Institute, Cary, NC). Data were based on ratings of single-plant plots, and each rating date was analyzed separately. 


\begin{tabular}{|c|c|c|c|c|c|c|c|c|c|}
\hline \multirow[b]{2}{*}{ Rank } & \multirow[b]{2}{*}{ Accession or cultivar } & \multirow[b]{2}{*}{ Country of origin } & \multicolumn{2}{|c|}{ Virus rating } & \multirow[b]{2}{*}{ ELISA test } & \multicolumn{4}{|c|}{ Virus rating } \\
\hline & & & Max. & Avg & & Rep1 & Rep2 & Rep3 & Rep4 \\
\hline \multicolumn{10}{|c|}{ Resistant } \\
\hline 1 & PI 595203 & Nigeria & 0.5 & 0.3 & $(-)$ & 0 & 1 & 0 & 1 \\
\hline 2 & PI 386019 & Iran & 0.7 & 0.6 & $(-)$ & 2 & 0 & 0 & - \\
\hline 3 & PI 490377 & Mali & 1.3 & 1 & $(-)$ & 1 & - & 0 & 3 \\
\hline 4 & PI 596662 & South Africa & 1.5 & 1.1 & $(-)$ & 0 & 2 & 1 & 3 \\
\hline 5 & PI 560016 & Nigeria & 1.8 & 1.1 & $(-)$ & 1 & 3 & 0 & 3 \\
\hline 6 & PI 494528 & Nigeria & 2 & 1.3 & $(-)$ & 2 & 2 & 2 & 2 \\
\hline 7 & PI 386025 & Iran & 2.3 & 1.6 & $(-)$ & 3 & 3 & 2 & 1 \\
\hline 8 & PI 595201 & Nigeria & 2.3 & 1.7 & $(-)$ & 3 & 3 & 1 & 2 \\
\hline 9 & PI 494530 & Nigeria & 2.3 & 1.9 & $(-)$ & 3 & 3 & 0 & 3 \\
\hline 10 & PI 485580 & Botswana & 2.5 & 1.4 & $(-)$ & 1 & 4 & 2 & 3 \\
\hline 11 & PI 386016 & Iran & 2.5 & 1.5 & $(-)$ & 2 & 3 & 2 & 3 \\
\hline 12 & PI 494529 & Nigeria & 2.8 & 2.2 & $(-)$ & 3 & 3 & 2 & 3 \\
\hline 13 & PI 386026 & Iran & 3 & 2.4 & $(-)$ & 1 & 3 & 4 & 4 \\
\hline 14 & PI 482265 & Zimbabwe & 3.3 & 2.3 & $(-)$ & 3 & 3 & 4 & 3 \\
\hline 15 & PI 485583 & Botswana & 3.3 & 2.3 & $(-)$ & 3 & 4 & 2 & 4 \\
\hline 16 & PI 244018 & South Africa & 3.3 & 2.7 & $(-)$ & 3 & 3 & 5 & 2 \\
\hline 17 & PI 386015 & Iran & 3.3 & 2.8 & $(-)$ & 4 & 3 & 3 & 3 \\
\hline 18 & PI 482286 & Zimbabwe & 3.3 & 2.8 & $(-)$ & 3 & 4 & 3 & 3 \\
\hline 19 & PI 482276 & Zimbabwe & 3.5 & 2.3 & $(-)$ & 3 & 4 & 3 & 4 \\
\hline 20 & PI 596696 & South Africa & 3.5 & 2.4 & $(-)$ & 4 & 4 & 3 & 3 \\
\hline 21 & PI 596668 & South Africa & 3.5 & 3 & $(-)$ & 4 & 3 & 3 & 4 \\
\hline 22 & PI 596659 & South Africa & 3.5 & 3.1 & $(-)$ & 3 & 3 & 4 & 4 \\
\hline 23 & PI 596669 & South Africa & 3.7 & 3.1 & $(-)$ & - & 4 & 3 & 4 \\
\hline 24 & PI 596671 & South Africa & 3.8 & 3.1 & $(-)$ & 3 & 4 & 3 & 5 \\
\hline 25 & PI 386018 & Iran & 3.8 & 3.2 & $(-)$ & 4 & 3 & 3 & 5 \\
\hline 26 & PI 244019 & South Africa & 3.8 & 3.3 & $(-)$ & 4 & 3 & 4 & 4 \\
\hline 27 & PI 482293 & Zimbabwe & 4 & 3 & $(-)$ & 4 & 4 & 4 & 4 \\
\hline 28 & PI 559992 & Nigeria & 4 & 3.1 & $(-)$ & 4 & 5 & 4 & 3 \\
\hline 29 & PI 485581 & Botswana & 4 & 3.2 & $(-)$ & 4 & 5 & 4 & 3 \\
\hline 30 & PI 595202 & Nigeria & 4 & 3.3 & $(-)$ & 3 & 4 & 5 & 4 \\
\hline 31 & PI 542119 & Botswana & 4 & 3.3 & $(-)$ & 3 & 4 & 4 & 5 \\
\hline \multicolumn{10}{|c|}{ Susceptible } \\
\hline 1 & PI 251244 & India & 9 & 8.4 & $(+)$ & 9 & 9 & 9 & 9 \\
\hline 2 & PI 381752 & India & 9 & 8.4 & $(+)$ & 9 & 9 & 9 & 9 \\
\hline 3 & PI 278058 & Turkey & 9 & 8.4 & $(+)$ & 9 & 9 & 9 & 9 \\
\hline 4 & PI 271987 & Somalia & 9 & 8.4 & $(+)$ & 9 & 9 & - & 9 \\
\hline 5 & PI 271750 & Ghana & 9 & 8.6 & $(+)$ & 9 & - & 9 & 9 \\
\hline 6 & PI 270143 & India & 9 & 8.8 & $(+)$ & - & 9 & - & 9 \\
\hline 7 & PI 269679 & Belize & 9 & 9 & $(+)$ & 9 & 9 & 9 & 9 \\
\hline 8 & PI 273480 & Ethiopia & 9 & 9 & $(+)$ & - & 9 & - & - \\
\hline 9 & PI 169241 & Turkey & 9 & 8.3 & $(+)$ & 9 & 9 & 9 & 9 \\
\hline 10 & PI 182935 & India & 9 & 8.3 & $(+)$ & 9 & 9 & 9 & 9 \\
\hline \multicolumn{10}{|c|}{ Checks } \\
\hline 1 & Charleston Gray & United States-South Carolina & 8.3 & 7.2 & $(+)$ & 8 & 8 & 9 & 8 \\
\hline 2 & Crimson Sweet & United States-Kansas & 8.8 & 7.8 & $(+)$ & 9 & 9 & 8 & 9 \\
\hline
\end{tabular}

${ }^{\mathrm{z}}$ Some countries listed as the origin of some accessions no longer exist as political units (Czechoslovakia, Soviet Union, Yugoslavia). Rank indicates the ranking of the cultigen for resistance to ZYMV based on average and maximum ratings. Plants were rated on a scale of 1 to 9 based on the severity of viral symptoms: $1=$ none; $2=$ tendrils absent; $3=$ tendrils absent, slightly stunted growth; $4=$ mosaic patches and/or necrotic spots on leaves; $5=$ leaves near apical meristem deformed, meristem yellow and reduced in size; $6=$ apical meristem withered and brown; $7=$ apical meristem dead with more basal leaves dying; $8=$ most leaves dead, main stem green/ yellow; $9=$ plant dead. ELISA test: $(-)=$ negative and $(+)=$ positive.

\section{Results and Discussion}

Germplasm screening. Not all 1654 accessions germinated in the four replications; data were obtained for only 1642 accessions. Twelve $(0.7 \%)$ PI accessions did not germinate in all four replications (missing data). These accessions were Grif 14201, Grif 14202, PI 271468, PI 271767, PI 274034, PI 381745, PI 386014, PI 532670, PI 542113, PI 542118, PI 596679, and PI 596691. There was no germination for $15 \mathrm{PI}$ accessions in three replications, 26 PI accessions in two replications, and 89 PI accessions in one replication; 1513 (91.5\%) PI accessions germinated in all four replications. The complete data set was submitted to the Germplasm Resources Information Network (GRIN; http://www.ars-grin.gov/) for those interested in the performance of particular accessions.
All 41 cultivars were susceptible, with viral symptom severity ratings of 8.0 to 9.0 (data not shown). The most resistant and most susceptible PI accessions are presented here, along with accessions with known virus susceptibility (control cultivars) (Table 1). The ANOVA indicated that there were highly significant differences $(P<0.01)$ among accessions for all rating dates (data not shown). The maximum and average ratings were highly correlated $(r=0.95)$, and the maximum rating had a smaller $F$ ratio than the weekly ratings (Table 1).

We identified resistant accessions using the average and maximum ratings. A rating of 3 indicated the highest genetic variance relative to error variance. Only those accessions with no virus in their system (according to ELISA test results) were considered for the resistance list. There were $31 \mathrm{PI}$ accessions that had a maximum rating of 4 or less (Table 1). This study reported resistance to ZYMV severe isolate 2088 (collected in Florida). However, it is possible that resistant accessions reported here may not have resistance to other isolates in other regions where ZYMV is found.

The issue of escapes is important. Studies of the resistance to WMV and PRSV-W found that some accessions that were initially rated as resistant were escapes (Guner et al., 2018a). We performed a retest of the resistant accessions to reduce the likelihood of escapes.

The susceptible control cultivars used in this study were the commonly used Charleston Gray and Crimson Sweet. However, we identified PI accessions with more 
Table 2. Maximum and average resistance ratings of the 46 most resistant and 8 most susceptible cultigens (along with check) of watermelon for ZYMV during the retest study. ${ }^{z}$

\begin{tabular}{|c|c|c|c|c|c|c|c|c|c|}
\hline \multirow[b]{2}{*}{ Rank } & \multirow[b]{2}{*}{ Accession or cultivar } & \multirow[b]{2}{*}{ Country of origin } & \multicolumn{2}{|c|}{ Virus rating } & \multirow[b]{2}{*}{ ELISA test } & \multicolumn{4}{|c|}{ Virus rating } \\
\hline & & & Max. & Avg & & Rep1 & Rep2 & Rep3 & Rep4 \\
\hline \multicolumn{10}{|c|}{ Resistant } \\
\hline 1 & PI 595203 & Nigeria & 0.8 & 0.3 & $(-)$ & 1 & 1 & 1 & 0 \\
\hline 2 & PI 537277 & Pakistan & 1.0 & 0.6 & $(-)$ & - & 1 & 1 & 1 \\
\hline 3 & PI 560016 & Nigeria & 1.5 & 1.0 & $(-)$ & 1 & 2 & 2 & 1 \\
\hline 4 & PI 386016 & Iran & 1.7 & 1.3 & $(-)$ & 1 & - & 2 & 2 \\
\hline 5 & PI 386019 & Iran & 2.0 & 1.3 & $(-)$ & 2 & 2 & 2 & 2 \\
\hline 6 & PI 485580 & Botswana & 2.3 & 1.7 & $(-)$ & 2 & 3 & 2 & 2 \\
\hline 7 & PI 494529 & Nigeria & 2.3 & 1.8 & $(-)$ & 2 & 2 & 3 & 2 \\
\hline 8 & PI 595200 & Nigeria & 2.3 & 1.8 & $(-)$ & 2 & 3 & 3 & 1 \\
\hline 9 & PI 494528 & Nigeria & 2.3 & 1.9 & $(-)$ & 2 & 3 & 2 & - \\
\hline 10 & PI 595201 & Nigeria & 2.5 & 1.6 & $(-)$ & 2 & 3 & 3 & 2 \\
\hline 11 & PI 386025 & Iran & 2.5 & 1.9 & $(-)$ & 2 & 3 & 2 & 3 \\
\hline 12 & PI 494530 & Nigeria & 2.5 & 2.0 & $(-)$ & 2 & 3 & 3 & 2 \\
\hline 13 & PI 386015 & Iran & 2.5 & 2.0 & $(-)$ & 2 & 2 & 3 & 3 \\
\hline 14 & PI 386021 & Iran & 2.7 & 2.1 & $(-)$ & 3 & 3 & 2 & - \\
\hline 15 & PI 386026 & Iran & 2.7 & 2.1 & $(-)$ & 3 & - & 2 & 3 \\
\hline 16 & PI 596662 & South Africa & 3.0 & 2.4 & $(-)$ & 2 & 3 & 3 & 4 \\
\hline 17 & PI 386018 & Iran & 3.8 & 3.0 & $(-)$ & 4 & 4 & 4 & 3 \\
\hline 18 & PI 595202 & Nigeria & 3.8 & 3.2 & $(-)$ & 4 & 3 & 4 & 4 \\
\hline 19 & PI 244018 & South Africa & 4.0 & 3.2 & $(-)$ & 4 & 4 & 4 & 4 \\
\hline 20 & PI 244019 & South Africa & 4.0 & 3.4 & $(-)$ & 4 & 4 & 4 & 4 \\
\hline 21 & PI 596696 & South Africa & 4.3 & 3.5 & $(-)$ & 4 & 5 & 4 & 4 \\
\hline 22 & PI 482286 & Zimbabwe & 4.5 & 3.5 & $(-)$ & 5 & 4 & 4 & 5 \\
\hline 23 & PI 490377 & Zimbabwe & 4.7 & 3.7 & $(-)$ & - & 4 & 5 & 5 \\
\hline 24 & PI 485583 & Botswana & 4.8 & 3.9 & $(-)$ & 4 & 5 & 4 & 6 \\
\hline 25 & PI 596659 & South Africa & 5.0 & 4.2 & $(-)$ & 5 & 5 & 5 & - \\
\hline 26 & PI 596669 & South Africa & 5.0 & 4.3 & $(-)$ & 2 & 6 & 7 & 5 \\
\hline 27 & PI 271770 & South Africa & 5.0 & 4.4 & $(-)$ & 5 & 5 & - & 5 \\
\hline 28 & PI 485581 & Botswana & 5.3 & 4.6 & $(-)$ & 5 & 6 & 6 & 4 \\
\hline 29 & PI 596668 & South Africa & 5.5 & 4.4 & $(-)$ & 6 & 6 & 5 & 5 \\
\hline 30 & PI 482276 & Zimbabwe & 5.8 & 4.8 & $(-)$ & 6 & 6 & 6 & 5 \\
\hline 31 & PI 549161 & Chad & 5.8 & 4.9 & $(-)$ & 5 & 5 & 7 & 6 \\
\hline 32 & PI 482265 & Zimbabwe & 5.8 & 5.0 & $(-)$ & 5 & 7 & 6 & 5 \\
\hline 33 & PI 559992 & Nigeria & 5.8 & 5.0 & $(-)$ & 6 & 6 & 7 & 4 \\
\hline 34 & PI 482342 & Zimbabwe & 5.8 & 5.1 & $(-)$ & 6 & 5 & 7 & 5 \\
\hline 35 & PI 482309 & Zimbabwe & 5.8 & 5.3 & $(-)$ & 5 & 5 & 8 & 5 \\
\hline 36 & PI 482308 & Zimbabwe & 6.0 & 5.2 & $(-)$ & 6 & 7 & 6 & 5 \\
\hline 37 & PI 596666 & South Africa & 6.0 & 5.3 & $(-)$ & 7 & 7 & 6 & 4 \\
\hline 38 & PI 482315 & Zimbabwe & 6.0 & 5.3 & $(-)$ & 5 & 7 & 6 & 6 \\
\hline 39 & PI 482273 & Zimbabwe & 6.3 & 5.4 & $(-)$ & 6 & 6 & 7 & 6 \\
\hline 40 & PI 500303 & Zambia & 6.3 & 5.4 & $(-)$ & 6 & 6 & 7 & 6 \\
\hline 41 & PI 532659 & Zimbabwe & 6.3 & 5.6 & $(-)$ & 5 & 7 & 7 & 6 \\
\hline 42 & PI 296334 & South Africa & 6.3 & 5.6 & $(-)$ & 6 & 8 & 6 & 5 \\
\hline 43 & PI 596671 & South Africa & 6.3 & 5.6 & $(-)$ & 6 & 6 & 7 & - \\
\hline 44 & PI 482293 & Zimbabwe & 6.5 & 5.6 & $(-)$ & 7 & 8 & 6 & 5 \\
\hline 45 & PI 512385 & Spain & 6.8 & 6.1 & $(-)$ & 7 & 7 & 7 & 6 \\
\hline 46 & PI 542119 & Botswana & 6.8 & 6.2 & $(-)$ & 5 & 7 & 9 & 6 \\
\hline \multicolumn{10}{|c|}{ Susceptible } \\
\hline 1 & PI 254429 & Lebanon & 8.7 & 8.0 & $(+)$ & - & 9 & 9 & 8 \\
\hline 2 & PI 482336 & Zimbabwe & 8.7 & 8.2 & $(+)$ & 8 & 9 & 9 & - \\
\hline 3 & PI 182935 & India & 8.8 & 8.2 & $(+)$ & 8 & 9 & 9 & 9 \\
\hline 4 & PI 278058 & Turkey & 8.8 & 8.2 & $(+)$ & 9 & 9 & 9 & 8 \\
\hline 5 & PI 269365 & Afghanistan & 8.8 & 8.3 & $(+)$ & 9 & 9 & 8 & 9 \\
\hline 6 & PI 176492 & Turkey & 9.0 & 8.4 & $(+)$ & 9 & 9 & 9 & 9 \\
\hline 7 & PI 270141 & India & 9.0 & 8.6 & $(+)$ & - & 9 & 9 & 9 \\
\hline 8 & Grif 5601 & India & 9.0 & 8.6 & $(+)$ & 9 & - & 9 & 9 \\
\hline 9 & PI 270143 & India & 9.0 & 8.7 & $(+)$ & 9 & 9 & 9 & 9 \\
\hline 10 & PI 269679 & Belize & 9.0 & 8.8 & $(+)$ & 9 & 9 & 9 & - \\
\hline \multicolumn{10}{|l|}{ Check } \\
\hline 1 & Crimson Sweet & United States-Kansas & 8.7 & 8.2 & $(+)$ & - & 8 & 9 & 9 \\
\hline
\end{tabular}

\footnotetext{
${ }^{\mathrm{z}}$ An analysis was performed for means of each rating date plus the overall averages. Plants were rated on a scale of 1 to 9 based on the severity of viral symptoms: $1=$ none; 2 = tendrils absent; 3 = tendrils absent, slightly stunted growth; $4=$ mosaic patches and/or necrotic spots on leaves; $5=$ leaves near apical meristem deformed, meristem yellow and reduced in size; $6=$ apical meristem withered and brown; $7=$ apical meristem dead with more basal leaves dying; $8=$ most leaves dead, main stem green/yellow; 9 = plant dead. Average rating is the mean of the ratings of all 54 plants. Maximum rating is the mean of the final rating of all 54 plants per PI accession. Rank indicates the ranking of the cultigen for resistance to ZYMV based on average and maximum ratings. ELISA test: $(-)=$ negative and $(+)=$ positive.
}

susceptibility to ZYMV. The PI accessions would make excellent susceptible controls because they have high germination rates and maximum ratings of 9.0 compared with 'Charleston Gray' and 'Crimson Sweet', which had maximum ratings of 8.3 and 8.8 , respectively (Table 1). Any of the following accessions could be used as susceptible controls: PI 251244, PI 381752, PI 278058, PI 271987, PI 271750, PI 270143, PI 269679, PI 273480, PI 169241, and PI 182935 (data in GRIN).
The PI accessions with the most resistance (maximum rating of 4.0 or less) and complete data (missing in no more than one replication) were PI 595203, PI 386019, PI 490377, PI 596662, PI 560016, PI 494528, PI 386025, PI 595201, PI 494530, PI 485580, PI 
Table 3. Variations among replications for resistant and susceptible cultigens (along with 2 checks) of watermelon for ZYMV resistance using a rating of 3 for each replication. ${ }^{\mathrm{z}}$

\begin{tabular}{|c|c|c|c|c|c|c|c|c|c|c|}
\hline \multirow[b]{2}{*}{ Rank } & \multirow[b]{2}{*}{ PI accession or cultivar } & \multirow[b]{2}{*}{ Country of origin } & \multicolumn{8}{|c|}{ Virus rating over replication } \\
\hline & & & 1 & 2 & 3 & 4 & 5 & 6 & 7 & 8 \\
\hline \multicolumn{11}{|c|}{$\overline{\text { Resistant }}$} \\
\hline 1 & PI 595203 & Nigeria & 0.0 & 1.0 & 0.0 & 1.0 & 1.0 & 1.0 & 1.0 & 0.0 \\
\hline 2 & PI 494528 & Nigeria & 2.0 & 2.0 & 2.0 & 2.0 & 2.0 & 3.0 & 2.0 & - \\
\hline 3 & PI 244019 & South Africa & 4.0 & 3.0 & 4.0 & 4.0 & 4.0 & 4.0 & 4.0 & 4.0 \\
\hline \multicolumn{11}{|c|}{ Susceptible } \\
\hline 1 & PI 270143 & India & - & 9.0 & - & 9.0 & 9.0 & 9.0 & 9.0 & 9.0 \\
\hline 2 & PI 269679 & Belize & 9.0 & 9.0 & 9.0 & 9.0 & 9.0 & 9.0 & 9.0 & - \\
\hline 3 & PI 182935 & India & 9.0 & 9.0 & 9.0 & 9.0 & 8.0 & 9.0 & 9.0 & 9.0 \\
\hline \multicolumn{11}{|c|}{ Checks } \\
\hline 1 & Charleston Gray & United States & 8.0 & 8.0 & 9.0 & 8.0 & - & - & - & - \\
\hline 2 & Crimson Sweet & United States & 9.0 & 9.0 & 8.0 & 9.0 & - & 8.0 & 9.0 & 9.0 \\
\hline
\end{tabular}

${ }^{\mathrm{z}}$ Analysis was performed for means of each rating date plus the overall averages.

386016, PI 494529, PI 386026, PI 482265, PI 85583, PI 244018, PI 386015, PI 482286, PI 482276, PI 596696, PI 596668, PI 596659, PI 596669, PI 596671, PI 386018, PI 244019, PI 482293, PI 559992, PI 485581, PI 595202, and PI 542119 (Table 1).

Our results paralleled those reported by other researchers. Provvidenti (1991) and Boyhan et al. (1992) working with ZYMV, Gillaspie and Wright (1993) working with WMV, and Strange et al. (2002) working with PRSV-W were able to identify resistant accessions in their watermelon studies. Four PI accessions that were found to be highly resistant to ZYMV-FL were PI 482308 (rating of 4.5), PI 482299 (rating of 5.5), PI 482322 (rating of 5.3), and PI 482261 (rating of 6.8) Provvidenti (1991); however, these did not show high resistance in our study. Two Nigerian Egusi PI accessions also identified as resistant to ZYMV-FL were PI 494528 (rating of 2.0) and PI 494532 (rating of 7.7) Provvidenti (1991); however, these had no resistance (PI 494532) or high resistance (PI 494528) in our study. Three PI accessions reported to be resistant to ZYMV were also found to be resistant in our screening study: PI 386025 (rating of 2.3), PI 386026 (rating of 3.0), and PI 595203 (rating of 0.5) Boyhan et al. (1992).

Interestingly, some of the accessions that were found to be resistant to WMV and PRSV-W in previous studies also had some level of resistance to ZYMV (Guner et al., 2018b; Strange et al., 2002). The PI accession 595203 was found to be resistant to PRSV-W by Strange et al. (2002), to the Florida strain of ZYMV (ZYMV-FL) by Boyhan et al. (1992), and to the Chinese strain of ZYMV (ZYMV-CH) and WMV by Xu et al. (2004); it was the most resistant to ZYMV according to the germplasm screening and retest studies by Gillaspie and Wright (1993). Therefore, PI 595203 appears to be resistant to ZYMVFL, ZYMV-CH, WMV, and PRSV-W.

PI 189316, PI 189317, PI 189318, PI 255137, PI 164708, PI 306782, and PI 388770 were reported to be resistant to WMV by Gillaspie and Wright (1993); however, it showed no resistance to ZYMV in our study. However, PI 244018 (rating of 3.3), PI 244019 (rating of 3.8), PI 386016 (rating of 2.5), PI 386024 (rating of 5.0), PI 386025, PI 386026, and PI 595203 showed some resistance to ZYMV.
PI 244018, PI 244019, PI 482342 (rating of 4.3), PI 485583 (rating of 3.3), and PI 595203 were found to be resistant to PRSV-W by Strange et al. (2002), and these also showed high resistance to ZYMV. PI 482318 and PI 482379 were reported to be resistant to PRSV$\mathrm{W}$; however, they were not resistant to ZYMV. PI 244017 (rating of 5.3) had the highest resistance to PRSV-W, but it had intermediate resistance to ZYMV in our study.

Finally, PI 386015 and PI 386016 were reported to be resistant to cucurbit yellow stunting disorder virus (CYSDV) by Lecoq et al. (1998), and they were resistant to ZYMV in our study.

Retest. The retest of the 46 most resistant PI accessions and the control cultivar, Crimson Sweet, showed that there were escapes that were not resistant to ZYMV (Table 2). Seven PI accessions were identified as resistant by the germplasm screening (PI 482265, PI 482276, PI 482293, PI 490377, PI 542119, PI 559992, and PI 596669), but they were only moderately resistant or susceptible according to the retest study (data not shown). The PI accessions with the most resistance (rating less than 4.0) that were missing in no more than one replication were PI 595203, PI 537277, PI 560016, PI 386016 , PI 386019, PI 485580, PI 494529, PI 595200, PI 494528, PI 595201, PI 386025, PI 494530, PI 386015, PI 386021, PI 386026, PI 596662, PI 386018, and PI 595202. PI 595203 had the highest resistance rating according to the germplasm screening and retest study.

Susceptible PI accessions that were tested during the retest study had approximately the same level of susceptibility to ZYMV as they did during the germplasm screening (Table 2). PI 269679 had the highest susceptible rating according to the retest study and the second highest rating according to the germplasm screening. There were 52 missing accessions that did not germinate in at least two replications during the germplasm screening that were included in the retest study. Of those, 19 failed to germinate during the retest study. Seven of 12 (missing in all four replications) accessions also did not germinate in all four replications during the retest study. However, none of the missing accessions (missing in all four replications) tested during the retest study had a high level of resistance to ZYMV (data not shown).
PI accession variability. We expected many PI accessions to be heterogeneous because they were collected in the wild and maintained by sib mating or open pollination. Therefore, accessions rated susceptible in this study may have a low frequency of resistant plants and could be identified by testing many plants per accession. It is also possible that resistant accessions have occasional susceptible plants. Therefore, researchers and breeders should self-pollinate and select the most resistant plants of the resistant accessions to develop resistant inbred lines for further use. In this study, the most resistant and most susceptible accessions identified for further research were just as uniform as the control cultivars, which were inbred lines (Table 3 ).

If resistance to ZYMV were polygenic in inheritance, then resistance might be improved by intercrossing the most resistant accessions or by crossing accessions with high resistance with accessions with moderate resistance. If the resistance to ZYMV were monogenic in inheritance, then the resistance could be incorporated in breeding lines from donor PIs by backcrossing. Then, improved breeding lines could be used for further development of resistant cultivars.

\section{Literature Cited}

Ali, A., O. Mohammad, and A. Khattab. 2012. Distribution of viruses infecting cucurbit crops and isolation of potential new virus-like sequences from weeds in Oklahoma. Plant Dis. 96:243-248.

Boyhan, G., J.D. Norton, B.J. Jacobsen, and B.R. Abrahams. 1992. Evaluation of watermelon and related germplasm for resistance to Zucchini yellow mosaic virus. Plant Dis. 76:251252.

Brown, R.N. 2001. Traditional and molecular approaches to Zucchini yellow mosaic virus resistance in Cucurbita. PhD Thesis. Dept. of Horticulture, Oregon State University, Corvallis, OR.

Cardoso, A.I.I., M.A. Pavan, R. Krause Sakate, and K. Fattori. 2010. Inheritance of cucumber tolerance to Zucchini yellow mosaic virus. J. Plant Pathol. 92:245-248.

Chen, K.-C., C.-H. Chiang, J.A.J. Raja, F.-L. Liu, C.-H. Tai, and S.-D. Yeh. 2008. A single amino acid of NIaPro of Papaya ringspot virus determines host specificity for infection of papaya. Mol. Plant Microbe Interact. 21:1046-1057. 
Coutts, B.A., M.A. Kehoe, and R.A.C. Jones. 2011. Minimising losses caused by Zucchini yellow mosaic virus in vegetable cucurbit crops in tropical, sub-tropical and Mediterranean environments through cultural methods and host resistance. Virus Res. 159:141-160.

Desbiez, C. and H. Lecoq. 1997. Zucchini yellow mosaic virus. Plant Pathol. 46:809-829.

FAO. 2015. FAO statistical pocketbook. FAO Statistic Division, Rome, Italy.

Fuchs, M. and D. Gonsalves. 1995. Resistance of transgenic hybrid squash ZW-20 expressing the coat protein genes of Zucchini yellow mosaic virus and Watermelon mosaic virus 2 to mixed infections by both potyviruses. Nat. Biotechnol. 13:1466-1473.

Gillaspie, A.G. and J.M. Wright. 1993. Evaluation of Citrullus sp. germplasm for resistance to Watermelon mosaic virus 2. Plant Dis. 77:352-354.

Guner, N. and T.C. Wehner. 2008. Overview of potyvirus resistance in watermelon, p. 445452. In: M. Pitrat (eds.). Cucurbitaceae 2008. Proceedings of the IXth EUCARPIA Meeting on Genetics and Breeding of Cucurbitaceae. Avignon, France.

Guner, N., E.B. Strange, T.C. Wehner, and Z. Pesic-VanEsbroeck. 2002. Methods for screening watermelon for resistance to Papaya ringspot virus type- $W$. Scientia Hort. 94:297-307.

Guner, N., Z. Pesic-VanEsbroeck, L.A. Rivera-Burgos, and T.C. Wehner. 2018a. Inheritance of resistance to Papaya ringspot virus-watermelon strain in watermelon. HortScience 53:624-627.

Guner, N., L.A. Rivera-Burgos, and T.C. Wehner. 2018b. Inheritance of resistance to Zucchini yellow mosaic virus in watermelon. HortScience 53:1115-1118.

Gusmini, G., L.A. Rivera-Burgos, and T.C. Wehner. 2017. Inheritance of resistance to gummy stem blight in watermelon. HortScience 52:14771482 .

Kabelka, E., Z. Ullah, and R. Grumet. 1997. Multiple alleles for Zucchini yellow mosaic virus resistance at zym locus in cucumber. Theor. Appl. Genet. 95:997-1004.

Lecoq, H., G. Wisler, and M. Pitrat. 1998. Cucurbit viruses: The classics and the emerging, p. 126142. In: J.D. McCreight (ed.). Cucurbitaceae '98. Evaluation and enhancement of cucurbit germplasm. ASHS Press, Alexandria, VA.
Levi, A., K.R. Harris-Shultz, and K.-S. Ling. 2016. USVL-370, a Zucchini yellow mosaic virusresistant watermelon breeding line. HortScience 51:107-109.

Ling, K.-S., K.R. Harris, J.D. Meyer, A. Levi, N. Guner, T.C. Wehner, A. Bendahmane, and M.J. Havey. 2009. Non-synonymous single nucleotide polymorphisms in the watermelon eIF4E gene are closely associated with resistance to Zucchini yellow mosaic virus. Theor. Appl. Genet. 120:191-200.

Lisa, V. and G. Dellavalle. 1981. Characterization of two potyviruses from zucchini squash. Phytopathology 100:279-286.

Morata, J. and P. Puigdomènech. 2017. Variability among Cucurbitaceae species (melon, cucumber and watermelon) in a genomic region containing a cluster of NBS-LRR genes. BMC Genomics 18:1-7.

Nagendran, K., S. Mohankumar, R. Aravintharaj, C.G. Balaji, S.K. Manoranjitham, A.K. Singh, A.B. Rai, B. Singh, and G. Karthikeyan. 2017. The occurrence and distribution of major viruses infecting cucurbits in Tamil Nadu state, India. Crop Prot. 99:10-16.

Namba, S., K. Ling, C. Gonsalves, J.L. Slightom, and D. Gonsalves. 1992. Protection of transgenic plants expressing the coat protein gene of Watermelon mosaic virus II or Zucchini yellow mosaic virus against six potyviruses. Phytopathology 82:940-946.

Paris, H.S. and R.N. Brown. 2005. The Genes of Pumpkin and Squash. HortScience 40:1620 1630.

Park, Y., N. Katzir, Y. Brotman, J. King, F. Bertrand, and M. Havey. 2004. Comparative mapping of ZYMV resistances in cucumber (Cucumis sativus L.) and melon (Cucumis melo L.). Theor. Appl. Genet. 109:707-712.

Perkins-Veazie, P., J.K. Collins, S.D. Pair, and W. Roberts. 2001. Lycopene content differs among red-fleshed watermelon cultivars. J. Sci. Food Agr. 81:983-987.

Pitrat, M. and H. Lecoq. 1984. Inheritance of Zucchini yellow mosaic virus resistance in Cucumis melo L. Euphytica 33:57-61.

Provvidenti, R. 1986. Reactions of PI accessions of Citrullus colocynthis to Zucchini yellow mosaic virus and other viruses. Rep. Cucurbit Genet. Coop. 9:82-83.
Provvidenti, R. 1991. Inheritance of resistance to the Florida strain of Zucchini yellow mosaic virus in watermelon. HortScience 26:407-408.

Romay, G., H. Lecoq, and C. Desbiez. 2014. Cucurbit crops and their viral diseases in Latin America and the Caribbean islands: A review. J. Plant Pathol. 96:227-242.

Strange, E.B., N. Guner, Z. Pesic-VanEsbroeck, and T.C. Wehner. 2002. Screening the watermelon germplasm collection for resistance to Papaya ringspot virus type-W. Crop Sci. 42: 1324-1330.

Tiwari, A.K. and G.P. Rao. 2014. Viruses infecting Cucurbita pepo: Current status and management, p. 357-371. In: R.N. Kharwar, R.S. Upadhyay, N.K. Dubey, and R. Raghuwanshi (eds.). Microbial Diversity and Biotechnology in Food Security. Springer India, New Delhi.

USDA. 2017. Agricultural statistics. Washington, D.C.

Wang, D., G. Li, and S.S. Du. 2017. Occurrence of viruses infecting melon in Xinjiang of China and molecular characterization of Watermelon mosaic virus isolates. Eur. J. Plant Pathol. 147: 919-931.

Webb, S.E. and R.V. Tyson. 1997. Evaluation of virus resistant squash varieties. Proc. Annu. Meet. Fla. State Hort. Soc. 110:299-302.

Wehner, T.C., N.V. Shetty, and G.W. Elmstrom. 2001. Breeding and seed production, p. 27-73. In: D.N. Maynard (ed.). Watermelon: Characteristics, production, and marketing. ASHS Press, Alexandria, VA.

Wisler, G.C., D.E. Purcifull, and E. Hiebert. 1995. Characterization of the $\mathrm{P} 1$ protein and coding region of the zucchini yellow mosaic virus. J. Gen. Virol. 76:37-45.

Xu, Y., D. Kang, Z. Shi, H. Shen, and T.C. Wehner. 2004. Inheritance of resistance to Zucchini yellow mosaic virus and Watermelon mosaic virus in watermelon. J. Hered. 96:498-502.

Yu, T.A., C.H. Chiang, H.W. Wu, C.M. Li, C.F. Yang, J.H. Chen, Y.W. Chen, and S.D. Yeh. 2011. Generation of transgenic watermelon resistant to Zucchini yellow mosaic virus and Papaya ringspot virus type W. Plant Cell Rep. 30:359-371. 